\title{
DISTRIBUTTION AND SUBSTRATE SPECIFICITY OF ESTERASES IN THE HOUSEFLY, MUSCA DOMESTICA L.
}

\author{
K. VAN ASPEREN \\ Lab. voor Insekticidenonderzoek, Vondellaan 6 Utrecht, Netherlands
}

(Received 29 December 1958)

\begin{abstract}
Housefly homogenates perform high cholinesterase and ali-esterase activity. Warburg-manometric studies show that acetylcholine, acetyl- $\beta$-methylcholine, butyrylcholine, and benzoylcholine are exclusively hydrolysed by a cholinesterase, the properties of which are more or less comparable to those of true vertebrate cholinesterase. Methylbutyrate and tributyrin are hydrolysed by one or possibly several ali-esterases but not by the cholinesterase. The cholinesterase activity is mainly present in the head and the ali-esterase activity in the thorax and the abdomen. Various other substrates, e.g. methylacetate, ethylacetate, amylacetate, triacetin, phenylacetate, and o-nitrophenylacetate are hydrolysed by both the cholinesterase and the ali-esterases. There is some evidence that o-nitrophenylacetate hydrolysis is partly due to an organophosphate-resistant enzyme distinct from the cholinesterase and ali-esterases, which are both inhibited by low concentrations of organophosphates. The ali-esterase activity is rapidly destroyed at $37^{\circ} \mathrm{C}$ in slightly alkaline media, whereas the cholinesterase is not affected by these conditions.
\end{abstract}

\section{INTRODUCTION}

THE presence of acetylcholine and of the enzymes for its synthesis and hydrolysis in several insect species is well established (CHAJWICK and HILL, 1947; Lewis, 1953; Lewis and Smallman, 1956; Chefurka and Smallman, 1956; SMALlman, 1956, 1958). It has been suggested that, as in mammals, the insecticidal action of organophosphorus compounds is due to their anticholinesterase properties (Metcalf, 1955; Metcalf, Fukuto, and March, 1958) and consequent disturbances in the levels and distribution of substrate (LEWIS and Fowler, 1956; Smallman, 1958; Smallman and Fischer, 1958; Colmoun, 1958). There is, however, also evidence that other esterases than cholinesterases may be important in organophosphate poisoning of insects (LORD and POTTER, 1950, 1951, 1954; PotTer et,al., 1957; HoPf, 1952, 1954; van AsPeren, 1957, 1958) and this prompted the present study on esterase activities in the adult houscfly.

\section{METHODS AND MATERIAL}

All the experiments were done with a normal strain of Musca domestica susceptible to insecticides. It was reared in the laboratory on a milk powder yeast diet at $25^{\circ} \mathrm{C}$ and 70 per cent relative humidity. Tests were made using homogenates of whole flies, heads, thoraces or abdomens. No attempt was made to purify the

* A part of the experimental work, especially that on the hydrolysis of o-nitrophenylacetate, was carried out by Mr. C. H. JANSSEN. 
enzymes. The following substrates were added to give the initial concentrations indicated in the tables: acetylcholine, acetyl- $\beta$-methylcholine, butyrylcholine, benzoylcholine, methylacetate, ethylacetate, amylacetate, phenylacetate, o-nitrophenylacetate, triacetin, methylbutyrate, ethylbutyrate, and tributyrin. An attempt was made to characterize the enzymes-(i) by their distribution between the head and the rest of the insect body, (ii) by their sensitivities to inhibition by DDVP, * paraoxon, $\uparrow$ and eserine, or (iii) by total activities in the presence of single and pairs of substrates.

Esterase activity was usually determined by the Warburg manometric method at $27^{\circ}$ or $37^{\circ} \mathrm{C}$ in a total volume of $2.2 \mathrm{ml}$ of solution, containing fly tissue and substrate at the concentrations required, $0.5 \mathrm{M} \mathrm{NaCl}$ and $0.025 \mathrm{M} \mathrm{NaHCO}_{3}$. The high concentration of $\mathrm{NaCl}$, according to CHADwICK, LOvELL, and EGNER (1953) and our own experiments proved to be favourable for the cholinesterase activity but not for the ali-esterase activity. In some experiments using methylbutyrate and tributyrin as substrates, therefore, $0.5 \mathrm{M}$ $\mathrm{NaCl}$ was replaced by $0.15 \mathrm{M} \mathrm{NaCl}$. In our view no striking differences may be expected from changing the $\mathrm{NaCl}$-concentration. A gas mixture containing 95 per cent $\mathrm{N}_{2}$ and 5 per cent $\mathrm{CO}_{2}$, was passed over the reaction fluid for some minutes before closing the manometers and flasks, the $\mathrm{pH}$ during the measurement of hydrolysis and during the incubation of homogenates with inhibitors was approximately 7.5 .

In some experiments the cholinesterase activity was measured by the colorimetric determination of acetylcholine as described by HesTrIN (1949). The hydrolysis of $o$-nitrophenylacetate was measured hy the colorimetric estimation of o-nitrophenol, as described by Hopr (1954). If one of the two colorimetric methods was used the enzymatic reaction took place in a physiological salt solution containing 0.01 or $0.1 \mathrm{M}$ phosphate buffer $\mathrm{pH}$ $6.9,0.8$ per cent $\mathrm{NaCl}, 0.04$ per cent $\mathrm{KCl}$ and 0.032 per cent $\mathrm{MgSO}_{4}$. As the yellow colour of $o$-nitrophenol is strongly dependent on $\mathrm{pH}$, dilution of the sample for use in the colorimeter cell was made with $0.1 \mathrm{M}$ phosphate buffer $\mathrm{pH} 6.9$ and the colour developed compared with the colour obtained with known amounts of $o$-nitrophenol at the same $\mathrm{pH}$. This procedure was especially necessary in those experiments where the hydrolysis caused a considerable change of $\mathrm{pH}$ during the reaction, e.g. in those cases where $0.01 \mathrm{M}$ phosphate buffer was used and acid production was high.

As it was found in the course of our investigations that part of the esterase activity is extremely heat-labile, especially in alkaline media, the conditions under which the homogenates were prepared and kept will be mentioned wherever this may be important for the interpretation of the results. The conditions used will be indicated by the letters $a, b$ and $c$, which are explained below.

(a) Flies or parts of flies were homogenized in a small type Waring blendor in $25 \mathrm{mM}$ bicarbonate-Ringer solution without cooling. The homogenates obtained were kept at room temperature until use in the Warburg-experiments, which were performed at $37^{\circ} \mathrm{C}$.

(b) Flies or parts of flies were homogenized in a small type Waring blendor in water or neutral salt solution with cooling in ice-water. The flasks containing the homogenates were kept in ice-water until use. In these experiments bicarbonate was mostly added at the very last moment before measurement of hydrolytic activity, which took place at $27^{\circ} \mathrm{C}$.

* DDVP $=$ O,O-dimethyl O-2,2 dichlorovinyl phosphate.

$\uparrow$ paraoxon $=0,0$-diethyl O-p-nitrophenyl phosphate. 
(c) Flies or parts of flies were homogenized in a mortar in phosphate buffer $\mathrm{pH} 6.9$, and hydrolytic activity was measured colorimetrically as described above.

Although no exact measurements on the influence of temperature on hydrolytic rates were made, the available evidence points to an increase between $27^{\circ} \mathrm{C}$ and $37^{\circ} \mathrm{C}$ of approximately 50 per cent in the case of cholinester-splitting and of less than that in the case of methylbutyrate- and tributyrin-hydrolysis. This should be taken into account whenever hydrolysis-rates obtained under $a$ - and $b$-conditions are compared.

\section{EXPERIMENTAL RESULTS}

\section{(A) Relation between activity and substrate concentration}

The rates at which several of the substrates under investigation were hydrolysed by homogenates of heads, thoraces and abdomens, or whole flies are shown in Table 1. Data shown on the same horizontal line of the table were obtained with a single homogenate. It is, therefore, possible to draw pS (- log substrate

TABle 1 - Hydrol ytic aCtivity OF HOMOGENATES

(Activities all expressed in $\mu \mathrm{l} \mathrm{CO}_{2} / 30 \mathrm{~min}$ )

\begin{tabular}{|c|c|c|c|c|c|c|c|c|c|c|c|}
\hline \multirow{2}{*}{ Substrate } & \multirow{2}{*}{ Homogenate } & \multirow{2}{*}{$\begin{array}{l}\text { Condi- } \\
\text { tions* }\end{array}$} & \multicolumn{9}{|c|}{ Substrate concentration (micromoles/litre) } \\
\hline & & & $1 \cdot 9$ & $3 \cdot 8$ & $7 \cdot 5$ & 15 & 30 & 60 & 120 & 240 & $\begin{array}{c}\text { emul- } \\
\text { sion }\end{array}$ \\
\hline Acetylcholine & 2 heads & $a$ & 103 & 110 & 112 & 106 & 91 & 76 & - & - & - \\
\hline Acetylcholine & 3 thoraces & $a$ & 85 & 105 & 108 & 105 & 87 & 63 & 45 & - & - \\
\hline $\begin{array}{l}\text { Acetyl- } \beta- \\
\text { methylcholine }\end{array}$ & 2 heads & $a$ & 15 & 21 & 24 & 30 & 30 & 26 & - & - & - \\
\hline Butyrylcholine & 2 heads & $a$ & 50 & 61 & 74 & 77 & 70 & 62 & - & 34 & - \\
\hline Benzoylcholine & 2 heads & $a$ & 4 & 5 & 5 & 6 & 5 & 5 & - & - & - \\
\hline Amylacetate & 2 heads & $a$ & 5 & 8 & 16 & 35 & - & 一 & - & 一 & 62 \\
\hline Triacetin & $2 \mathrm{~h}$ & $a$ & 38 & 60 & 90 & 123 & 148 & - & 169 & - & 一 \\
\hline $\begin{array}{l}o \text {-Nitrophenyl- } \\
\text { acetate }\end{array}$ & 2 heads & $a$ & 一 & $89 \dagger$ & - & - & - & - & - & - & $\longrightarrow$ \\
\hline Phenylacetate & $1 \mathrm{fly}$ & $b$ & - & - & $217+$ & 一 & - & - & 一 & - & - \\
\hline Methylbutyrate & $1 \mathrm{fly}$ & $b$ & - & 25 & 45 & 94 & 193 & 353 & 409 & - & - \\
\hline Ethy & $1 \mathrm{fly}$ & $b$ & 9 & 21 & 40 & 85 & 177 & - & - & - & 351 \\
\hline Tributyrin & $1 \mathrm{fly}$ & $b$ & - & - & - & - & - & - & - & - & 106 \\
\hline
\end{tabular}

* See Section 'Methods and Material'.

$\dagger$ Corrected for ionization of $o$-nitrophenol $\left(\mathrm{pK}_{37^{\circ}}=7 \cdot 04\right)$; actual $\mathrm{CO}_{2}$-production $/ 30 \mathrm{~min} / 2$ heads $=156 \mu 1$.

$\ddagger$ Actual concentration $9 \times 10^{-3} \mathrm{M}$.

concentration) activity curves for many of the substrates studied. Comparison of hydrolysis-rates for different substrates along vertical lines in the table, however, is liable to error since the hydrolytic activity of individual homogenates may vary to some extent. 


\section{(B) Distribution in the housefly body}

When two substrates are hydrolysed by the same enzyme it is reasonable to expect the distribution of the activities to these substrates over different parts of the insect body to be similar. This will not hold, of course, where one of these substrates is split by a second enzyme.

The experimental procedure used was simple. Flies were decapitated and the activities shown by homogenates of the heads and by homogenates of the trunk (this term indicates thorax, abdomen and all the appendages) were compared. In many experiments thorax and abdomen were also separated and their activities separately determined. The results can be found in Table 2 .

TABLE 2-DistribUTION OF HYDROLYTIC ACTIVITY

(All experiments were performed under $b$-conditions)

\begin{tabular}{l|c|c|c|c|c}
\hline \multirow{2}{*}{ Substrate } & \multirow{2}{*}{$\begin{array}{c}\text { Concentration } \\
\text { moles/litre }\end{array}$} & \multicolumn{3}{|c|}{ Percentage of total activity } \\
\cline { 3 - 6 } & head & thorax & trunk & abdomen \\
\hline Acetylcholinet & $1.5 \times 10^{-2}$ & 68 & 27 & 32 & 5 \\
Acetyl- $\beta$-methylcholine & $1.5 \times 10^{-2}$ & 72 & - & 28 & - \\
Butyrylcholine & $1.5 \times 10^{-2}$ & 67 & - & 33 & - \\
Triacetin & $5 \times 10^{-2}$ & 53 & - & 47 & - \\
Phenylacetate & $9 \times 10^{-3}$ & 34 & - & 66 & - \\
Methylbutyrate & $4.8 \times 10^{-2}$ & 21 & 41 & 79 & 38 \\
Tributyrin & emulsion & 22 & 36 & 78 & 42 \\
\hline
\end{tabular}

* Trunk $=$ thorax + abdomen.

$\dagger$ The data in the table were obtained with the Warburg-manometric method. They could be confirmed by experiments in which acetylcholine determinations were made by the colorimetric method described by Hestrin (1949).

\section{(C) Inhibition-experiments with organophosphates and eserine}

A further means of distinguishing the enzymes may be achieved by the determination of the inhibition caused by different inhibitors. The inhibitors used are DDVP, paraoxon, and eserine. A few remarks on esterase inhibition by these compounds need to be made in advance, since there exist several misunderstandings on this subject, which may lead to misinterpretation of the experimental results.

The organophosphorus compounds are irreversible inhibitors. The inhibition by these substances will increase as long as free inhibitor is present. The inhibitor molecules will be distributed over different hydrolytic enzymes and, perhaps, other proteins, and the degrce of inhibition finally obtained for different enzymes will depend on their respective affinities for the inhibitor molecules, the rate at which inhibition becomes irreversible, and the total amount of inhibitor added.

In our experiments (Table 3) the time available for the reaction between the inhibitor and the components of the homogenate is sufficiently long for the inhibitor to be substantially used. Under these circumstances proportionality between $I_{50}$ and homogenate concentration is to be expected. The problems 
concerned with the kinetics of enzyme inhibition by DDVP have recently been dealt with in detailed publications (VAN ASPEREN, 1958a; vaN ASPEREN and DEkHUIJZEN, 1958).

In contrast to the organic phosphates eserine is a reversible inhibitor which can be displaced from the enzyme by its substrate even after long incubation periods so that the relative affinities and concentrations of inhibitor and substrates are of paramount importance whereas the total amounts are of little consequence.

'Ihe following results were obtained :

(1) The hydrolysis of all substrates studied was strongly inhibited by DDVP and paraoxon. Under the experimental conditions used, the $I_{50}$ values were always lower than $10^{-8} \mathrm{M}$ and in many cases even lower than $10^{-9} \mathrm{M}$. Susceptibility to inhibition varies considerably, which makes direct comparison of $I_{50}$ values obtained in different experiments unreliable. As might be expected the homogenates of whole flies in general require higher inhibitor concentrations than those of fly-heads to obtain a given inhibition.

Evidence was obtained that even high concentrations of DDVP and paraoxon are unable to give full inhibition of hydrolysis if o-nitrophenylacetate is used as a substrate. Only about 70 per cent inhibition of trunk homogenates was obtained with $10^{-7}$ or $10^{-6} \mathrm{M}$ concentrations of these organophosphates. Probably, therefore, part of the hydrolysis of this substrate is brought about by some

TABLE 3-INHIBITION OF HYDROLYSIS BY DDVP

Incubation time $1.5 \mathrm{hr}$. Experiments $1-4$ were performed under $a$-conditions;

Experiment 5 was performed under $c$-conditions

\begin{tabular}{|c|c|c|c|c|c|c|c|}
\hline Substrate & $\begin{array}{l}\text { Homo- } \\
\text { genate }\end{array}$ & $\begin{array}{c}\text { Activity } \\
\left(\mu 1 \mathrm{CO}_{2} / 30 \mathrm{~min}\right)\end{array}$ & $\begin{array}{l}\text { Inhibito } \\
\text { and perc }\end{array}$ & $\begin{array}{l}\text { r-con } \\
\text { enta }\end{array}$ & $\begin{array}{l}\text { centration } \\
\text { je inhibiti }\end{array}$ & & $\begin{array}{l}\text { No. of } \\
\text { experiment }\end{array}$ \\
\hline $\begin{array}{l}\text { Acetylcholine } \\
\text { Butyrylcholine }\end{array}$ & $\begin{array}{c}\text { heads } \\
2 \cdot 5 \\
2 \cdot 5\end{array}$ & $\begin{array}{r}156 \\
91\end{array}$ & $\begin{array}{l}1.5 \times 10^{-9} \\
1.5 \times 10^{-9}\end{array}$ & $\begin{array}{l}\% \\
62 \\
69\end{array}$ & $\begin{array}{l}3 \times 10^{-9} \\
3 \times 10^{-9}\end{array}$ & $\begin{array}{l}\% \\
89 \\
96\end{array}$ & 1 \\
\hline $\begin{array}{l}\text { Acetylcholine } \\
\text { Triacetin }\end{array}$ & $\begin{array}{l}2 \\
2\end{array}$ & $\begin{array}{l}126 \\
134\end{array}$ & $\begin{array}{l}10^{-9} \\
10^{-9}\end{array}$ & $\begin{array}{l}56 \\
54\end{array}$ & $\begin{array}{l}2 \times 10^{-9} \\
2 \times 10^{-9}\end{array}$ & $\begin{array}{l}89 \\
90\end{array}$ & 2 \\
\hline $\begin{array}{l}\text { Acetylcholine } \\
\text { Acetyl- } \beta- \\
\text { methylcholine } \\
\text { Benzoylcholine }\end{array}$ & $\begin{array}{r}2 \\
6 \\
12\end{array}$ & $\begin{array}{r}129 \\
93 \\
31\end{array}$ & $\begin{array}{c}10^{-9} \\
3 \times 10^{-9} \\
6 \times 10^{-9}\end{array}$ & $\begin{array}{l}58 \\
51 \\
52\end{array}$ & & & 3 \\
\hline $\begin{array}{l}\text { Acetylcholine } \\
\text { Amylacetate }\end{array}$ & $\begin{array}{l}3 \\
3\end{array}$ & $\begin{array}{r}181 \\
94\end{array}$ & $\begin{array}{l}0.9 \times 10^{-9} \\
1.0 \times 10^{-9}\end{array}$ & $\begin{array}{l}50 \\
50\end{array}$ & & & 4 \\
\hline $\begin{array}{l}\text { Acetylcholine } \\
\text { o-Nitrophenyl- } \\
\text { acetate }\end{array}$ & $\begin{array}{l}1 \\
1\end{array}$ & $\begin{array}{l}1 \cdot 6^{*} \\
0.9 *\end{array}$ & $\begin{array}{l}10^{-9} \\
10^{-9}\end{array}$ & $\begin{array}{l}54 \\
59\end{array}$ & $\begin{array}{l}2 \times 10^{-9} \\
2 \times 10^{-9}\end{array}$ & $\begin{array}{l}81 \\
80\end{array}$ & 5 \\
\hline
\end{tabular}

* Activity expressed as $\mu$ moles $/ 30 \mathrm{~min}$.

† In moles/litre. 
organo-phosphate-resistant enzyme. This confirms the findings of METCALF et al., (1955) as to the presence of an organophosphate insensitive 'aromatic esterase'.

(2) When two substrates are hydrolysed by the same enzyme, the inhibition caused by a certain amount of inhibitor will be equal, provided the homogenate concentrations used in the experiments are equal. The inhibition values were, therefore, compared for pairs of substrates (Table 3 ).

(3) Inhibition studies with eserine gave the following results. The $I_{50}$ value for the hydrolysis of acetylcholine proved to be approximately $5 \times 10^{-9} \mathrm{M}$, whereas the $I_{50}$ value for the hydrolysis of methylbutyrate and tributyrin was higher than $2 \times 10^{-4}$ M. A large number of experiments were performed in which the inhibition of hydrolytic activities to different substrates by high concentrations of eserine $\left(10^{-4}-10^{-6} \mathrm{M}\right)$ was measured. The results are shown in Table 4.

TABLE 4 -INHIBITION OF HYDROLYSIS BY ESERINE

\begin{tabular}{|c|c|c|c|c|c|c|}
\hline Substrate & $\begin{array}{c}\text { Concen- } \\
\text { tration } \\
\text { (moles/ } \\
\text { litre) }\end{array}$ & Homogenate & $\begin{array}{l}\text { Condi- } \\
\text { tions }\end{array}$ & $\begin{array}{l}\text { Activity } \\
\left(\mu 1 \mathrm{CO}_{2} /\right. \\
30 \mathrm{~min})\end{array}$ & $\begin{array}{c}\text { Eserine- } \\
\text { concen- } \\
\text { tration } \\
\text { (moles } / \\
\text { litre) }\end{array}$ & $\begin{array}{l}\text { Inhibition } \\
\text { (per cent) }\end{array}$ \\
\hline Acetylcholine & $5 \times 10^{-2}$ & 2 whole flies & $b$ & 100 & $10^{-5}$ & 97 \\
\hline $\mathrm{ch}$ & $.5 \times 10^{-2}$ & 2 whole flies & $b$ & 28 . & $10^{-5}$ & 100 \\
\hline aoline & $5 \times$ & $2 \mathrm{wl}$ & $b$ & 70 & $10^{-5}$ & 100 \\
\hline Tri & $5 \times 10^{-}$ & 2 whole flies & $b$ & 186 & $10^{-5}$ & 68 \\
\hline Triacetin & $5 \times 10^{-2}$ & 2 trur & $b$ & 91 & $10^{-5}$ & 44 \\
\hline Amylacetate & emulsion & 2 whole flies & $b$ & 114 & $10^{-5}$ & 49 \\
\hline cetate & $2 \times 10^{-1}$ & $2 \mathrm{w}$ & $b$ & 7 & $10^{-5}$ & 8 \\
\hline $\mathrm{Et}$ & $2 \times$ & $2 w$ & $h$ & 66 & $10^{-5}$ & 15 \\
\hline ite & $9 \times$ & $1 \mathrm{w}$ & $b$ & 215 & $10^{-5}$ & 20 \\
\hline tate & $9 \times 10^{-3}$ & $1 \mathrm{tr}$ & $b$ & 143 & $10^{-5}$ & 17 \\
\hline & $9 \times 10^{-3}$ & & $h$ & 14 & $10^{-5}$ & 64 \\
\hline cetate & $3.6 \times 10^{-3}$ & $1 \mathrm{t}$ & $a$ & 69 & $10^{-6}$ & 25 \\
\hline & $10^{-3}$ & & $a$ & 9 & $10^{-6}$ & 87 \\
\hline etate & $3.6 \times 10^{-3}$ & 1 abdomen & $a$ & 21 & $10^{-6}$ & 31 \\
\hline & $2 \times 10^{-3}$ & 0.4 he & s & $0 \cdot 6$ & $10^{-6}$ & 69 \\
\hline etate & $2 \times 10$ & 0.4 & 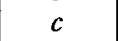 & $1 \cdot 1 \uparrow$ & $10^{-6}$ & 15 \\
\hline & $4 \times 10^{-}$ & & $c$ & $0.4 \dagger$ & $10^{-6}$ & \\
\hline etate & $4 \times 10^{-3}$ & unk* & -7 & $1 \cdot 1 \uparrow$ & $10^{-6}$ & 23 \\
\hline M & $4.8 \times 10^{-2}$ & 1 whole fly & $b$ & 352 & $10^{-5}$ & 3 \\
\hline & & & $a$ & 9 & $10^{-6}$ & \\
\hline Tributyrin & emulsion & 3 trunk* & $a$ & 90 & $10^{-4}$ & 33 \\
\hline
\end{tabular}

* Trunk $=$ thorax + abdomen.

$\dagger$ Activity expressed as $\mu$ moles $/ 30 \mathrm{~min}$.

$\$$ Data obtained in the same experiment.

\section{(D) Summation experiments}

Experiments in which one homogenate is allowed to act on a mixture of two substrates may be used to decide whether one enzyme acts on both substrates or, if there are two enzymes, one for each substrate. Due attention, however, should 
be paid to possibilities such as cross-inhibition (Golostein, 1954) and to the effect of substrate concentration. Lack of summation is evidence in favour of the occurrence of only one enzyme splitting both substrates, but it is no definite proof for it. Summation of activities may be considered as an indication for the presence of two enzymes only when near-saturation substrate concentrations are used.

The experimental results are to be found in the Tables 5 and 6 .

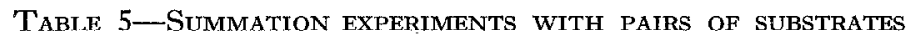
All experiments were under $a$-conditions, except Experiment 9 where $b$-conditions were used. All activities expressed in $\mu \mathrm{l} \mathrm{CO} / 30 \mathrm{~min}$; concentrations in moles/litre.

\begin{tabular}{|c|c|c|c|c|c|c|c|}
\hline & & & & & & & $\begin{array}{c}\text { No. } \\
\text { Experiment }\end{array}$ \\
\hline \multirow[t]{2}{*}{$2 \cdot 4$ heads } & $\begin{array}{l}\text { Acetylcholine-conc. } \\
\text { Butyrylcholine-conc. }\end{array}$ & ${ }^{3 \times 10^{-9}}$ & $\begin{array}{c}1.5 \times 10^{-2} \\
-\end{array}$ & $\begin{array}{l}1.5 \times 10^{-3} \\
1.5 \times 10^{-2}\end{array}$ & $1.5 \overline{1} \times 0^{-2}$ & $3 \overline{3 \times 10^{-2}}$ & \multirow{2}{*}{1} \\
\hline & Activity & 126 & 142 & 84 & 84 & 76 & \\
\hline \multirow[t]{2}{*}{$2 \cdot 4$ heads } & $\begin{array}{l}\text { Acetylcholine-conc. } \\
\text { Butyrylcholine-conc. }\end{array}$ & $\begin{array}{c}3.6 \times 10^{-1} \\
-\end{array}$ & $1.5 \times 10^{-2}$ & $\begin{array}{l}3.6 \times 10^{-1} \\
1.5 \times 10^{-2}\end{array}$ & $\begin{array}{l}1.5 \times 10^{-2} \\
1.5 \times 10^{-2}\end{array}$ & $1 . \overline{5 \times 10^{-2}}$ & \multirow[t]{2}{*}{2} \\
\hline & Activity & 29 & 161 & 24 & 94 & 95 & \\
\hline \multirow[t]{2}{*}{$2 \cdot 4$ heads } & $\begin{array}{l}\text { Acetylcholine-conc. } \\
\text { Butyrylcholine-conc. }\end{array}$ & $\begin{array}{c}1.2 \times 10^{-1} \\
-\end{array}$ & $\begin{array}{c}4.5 \times 10^{-2} \\
-\end{array}$ & $\begin{array}{l}1.2 \times 10^{-1} \\
1.5 \times 10^{-2}\end{array}$ & $\begin{array}{l}4.5 \times 10^{-2} \\
1.5 \times 10^{-2}\end{array}$ & $1 . \overline{5 \times 10^{-2}}$ & \multirow{2}{*}{3} \\
\hline & Activity & 81 & 122 & 67 & 82 & 91 & \\
\hline \multirow[t]{2}{*}{$2 \cdot 4$ heads } & $\begin{array}{l}\text { Acetylcholine-conc. } \\
\text { Benzoylcholine-conc. }\end{array}$ & $1.5 \times 10^{-2}$ & $1 . \overline{5 \times 10^{-2}}$ & $-2 \overline{3 \times 10^{-2}}$ & $\begin{array}{l}1.5 \times 10^{-2} \\
0.4 \times 10^{-2}\end{array}$ & $\begin{array}{rr}1.5 \times 10^{-2} & 1.5 \times 10^{-2} \\
1.5 \times 10^{-2} & 3 \times 10^{-2}\end{array}$ & \multirow{2}{*}{4} \\
\hline & Activity & 135 & 5 & 0 & 76 & 11 & \\
\hline \multirow[t]{2}{*}{$2 \cdot 4$ heads } & $\begin{array}{l}\text { Acetylcholine-conc. } \\
\text { Acetyl- } \beta \text {-methylcholine-conc. }\end{array}$ & $\begin{array}{c}1.5 \times 10^{-2} \\
-\end{array}$ & $1.5 \times 10^{-2}$ & $3 \times 10^{-2}$ & $\begin{array}{l}1.5 \times 10^{-2} \\
0.4 \times 10^{-2}\end{array}$ & $\begin{array}{rr}1.5 \times 10^{-2} & 1.5 \times 10^{-2} \\
1.5 \times 10^{-2} & 3 \times 10^{-2}\end{array}$ & \multirow[t]{2}{*}{5} \\
\hline & Activity & 151 & 48 & 50 & 152 & 112 & \\
\hline \multirow[t]{2}{*}{$2 \cdot 0$ heads } & $\begin{array}{l}\text { Acetylcholine-conc. } \\
\text { Triacetin-conc. }\end{array}$ & $1.5 \times 10^{-2}$ & $1.5 \times 10^{-2}$ & $7.5 \times \overline{10^{-2}}$ & $\begin{array}{l}1.5 \times 10^{-2} \\
0.4 \times 10^{-2}\end{array}$ & 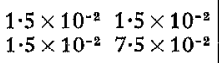 & \multirow{2}{*}{6} \\
\hline & Activity & 142 & 106 & 162 & 126 & 116 & \\
\hline \multirow[t]{2}{*}{2.0 heads } & $\begin{array}{l}\text { Acetylcholine-conc. } \\
\text { Methylbutyrate-conc. }\end{array}$ & $1 \cdot 5 \times 10^{-2}$ & $1.5 \times 10^{-2}$ & $4 \overline{1} \times 10^{-2}$ & $\begin{array}{l}1.5 \times 10^{-2} \\
0.5 \times 10^{-2}\end{array}$ & $\begin{array}{rr}1.5 \times 10^{-2} & 1.5 \times 10^{-2} \\
1.5 \times 10^{-8} & 4 \times 10^{-2}\end{array}$ & \multirow[t]{2}{*}{7} \\
\hline & Activity & 126 & 6 & 10 & 128 & 121 & \\
\hline \multirow[t]{2}{*}{2.0 heads } & $\begin{array}{l}\text { Acetylcholine-conc. } \\
\text { Methylbutyrate-conc. }\end{array}$ & $1.5 \times 10^{-2}$ & $1.2 \times 10^{-1}$ & $\begin{array}{l}1.5 \times 10^{-2} \\
1.2 \times 10^{-1}\end{array}$ & & & \multirow[t]{2}{*}{8} \\
\hline & Activity & 135 & 10 & 130 & & & \\
\hline \multirow[t]{2}{*}{2.5 heads } & $\begin{array}{l}\text { Acetylcholine-conc. } \\
\text { Methylbutyrate-conc. }\end{array}$ & $\begin{array}{c}1.5 \times 10^{-2} \\
-\end{array}$ & $4.8 \times 10^{-2}$ & $\begin{array}{l}1.5 \times 10^{-2} \\
4.8 \times 10^{-2}\end{array}$ & & & \multirow[t]{2}{*}{9} \\
\hline & Activity & 121 & 85 & 187 & & & \\
\hline \multirow[t]{2}{*}{$2 \cdot 0$ heads } & $\begin{array}{l}\text { Acetylcholine-conc. } \\
\text { Amylacetate-conc. }\end{array}$ & $1.5 \times 10^{-2}$ & emulsion & $\begin{array}{l}1.5 \times 10^{-2} \\
\text { emulsion }\end{array}$ & & & \multirow[t]{2}{*}{10} \\
\hline & Activity & 119 & 63 & 107 & & & \\
\hline
\end{tabular}


The experiments shown in Table 6 allowed of a calculation of the hydrolysis of both substrates (acetylcholine (ACh) and $o$-nitrophenylacetate (NPA)) separately, since NPA-hydrolysis was measured by the colorimetric determination of $a$ nitrophenol and the total hydrolysis by the Hestrin-method. The part of the two substrates in the total hydrolysis is shown in the last vertical column of Table 6.

TABLE 6-Summation EXPERIMENTS WITH ACETYLCHOLINE AND O-NITROPHENYLACETATE

Experiments performed under $c$-conditions.

All activities expressed in $\mu$ moles/30 min; concentrations in moles/litre

\begin{tabular}{l|l|c|c|c|c|c}
\hline 0.5 heads & $\begin{array}{c}\text { *ACh-conc. } \\
\text { †NPA-conc. }\end{array}$ & $\begin{array}{c}10^{-3} \\
\text { Experiment 1 }\end{array}$ & $\begin{array}{c}2 \times 10^{-3} \\
-\end{array}$ & $\begin{array}{c}- \\
10^{-3}\end{array}$ & $\begin{array}{c}- \\
2 \times 10^{-3}\end{array}$ & $\begin{array}{l}10^{-3} \\
10^{-3}\end{array}$ \\
\cline { 2 - 6 } & Activity & 0.72 & 0.85 & 0.57 & 0.60 & $0.76 / \begin{array}{l}0.45 \mathrm{ACh} \\
0.31 \mathrm{NPA} \\
0.72 \mathrm{ACh} \\
0.36 \mathrm{NPA}\end{array}$ \\
\hline
\end{tabular}

$* \mathrm{ACh}=$ Acetylcholine.

$\dagger \mathrm{NPA}=o$-Nitrophenylacetate.

(E) Additional experimental observations

Some observations which are of great importance for the present subject need be mentioned here, though it is hoped to publish a more detailed study in a separate paper.

Table 7-Loss of hydrolysing CAPACITy OF homogenates

Homogenates prepared in Bicarbonate-Ringer*

Substrates: $\mathrm{MB}=$ Methylbutyrate $; \mathrm{TB}=$ Tributyrin

\begin{tabular}{l|c|c|c|c|c|c|c}
\hline Homogenate & $\begin{array}{c}\text { Sub- } \\
\text { strate }\end{array}$ & $\begin{array}{c}\text { Activity } \\
(\mu \mathrm{l} \mathrm{CO} / 30 \mathrm{~min})\end{array}$ & $\begin{array}{c}\text { Temperature } \\
\left({ }^{\circ} \mathrm{C}\right) \ddagger\end{array}$ & \multicolumn{2}{|c|}{ Percentage of activity left after } \\
\hline 1 whole fly & MB & 364 & 26 & - & 88 & 55 & 27 \\
3 whole flies & TB & 410 & 26 & - & 83 & 46 & 39 \\
1 whole fly & MB & 306 & 36 & 58 & 24 & 18 & 15 \\
3 whole flies & TB & 369 & 36 & - & 55 & 44 & 38 \\
\hline
\end{tabular}

* Bicarbonate-Ringer contains $0.5 \mathrm{M} \mathrm{NaCl}$ and $0.025 \mathrm{M} \mathrm{NaHCO}_{3} ; \mathrm{pH}$ of the homogenate is approximately $8 \cdot 3$.

$\uparrow$ Activities measured at $27^{\circ} \mathrm{C}$ and $\mathrm{pH} 7.5$.

$\ddagger$ Temperature at which the homogenates are kept for the periods indicated.

(1) The capacity of housefly homogenates to hydrolyse acetylcholine remains constant for at least several hours at $37^{\circ} \mathrm{C}$. A homogenate of whole flies lost only 1 per cent of its hydrolysing activity to acetylcholine if kept 2 hr at $37^{\circ} \mathrm{C}$. Keeping a homogenate for $24 \mathrm{hr}$ at room temperature $\left(\mathrm{ca} .20^{\circ} \mathrm{C}\right)$ caused only 4 per cent loss of activity. 
The capacity of homogenates to split methylbutyrate or tributyrin, however, was found to decrease very rapidly (Table 7). Heating to $50^{\circ} \mathrm{C}$ reduced the hydrolytic activity of a whole fly homogenate to methylbutyrate $(340 \mu \mathrm{l}$ $\left.\mathrm{CO}_{2} / 30 \mathrm{~min}\right)$ to 69 per cent, 28 per cent, 16 per cent, and 4 per cent after 1,24 , and $8 \mathrm{~min}$ respectively. One minute heating to $100^{\circ} \mathrm{C}$ destroyed all activity.

All data as given refer to experiments in which the homogenates were prepared in physiological salt solutions containing $0.025 \mathrm{MI}$ sodium bicarbonate. These homogenates, therefore, were slightly alkaline. When 5 per cent $\mathrm{CO}_{2}-$ 95 per cent $\mathrm{N}_{2}$ gas mixture was passed over the 'bicarbonate-Ringer-homogenates' with consequent lowering of $\mathrm{pH}$, the inactivation at $37^{\circ} \mathrm{C}$ was very much slower. The inactivation rate was also much lower when the homogenates were prepared in neutral salt solutions. Most probably, therefore, the rate of inactivation is strongly dependent upon the concentration of hydroxyl-ions in the medium. Almost no inactivation took place if methyl butyrate was added to the homogenate. This could be due to a protective effect of the substrate, but the hydrolysis of the methylbutyrate causes a rapid fall in $\mathrm{pH}$ which would also account for the increased stability.

These observations, made in the course of our experimental work on the present subject, induced us to change our techniques of preparing and keeping the homogenates as described before, see method (b) instead of method (a).

(2) A second point, which held our attention, was the absence of proportionality between homogenate concentration and hydrolytic activity in many experiments with methylbutyrate and tributyrin. At low homogenate concentrations the activity was much less than would be expected assuming proportionality. This may be illustrated by the results of some typical experiments on methylbutyrate hydrolysis. A whole fly homogenate when diluted 4 and 8 times showed only 7 per cent and 1 per cent of the activity of an undiluted sample (activity $287 \mu \mathrm{l} \mathrm{CO} / 30 \mathrm{~min}$ ) respectively. When flyhead homogenates containing 6, 4, 3,2 , and 1 heads per $\mathrm{ml}$ were compared the activities $\left(\mu \mathrm{l} \mathrm{CO}_{2} / 30 \mathrm{~min}\right.$ ) proved to be $416,272,196,128$, and 38 respectively. These findings were qualitatively confirmed in several other experiments. The degree of disproportion, however, varied a great deal.

No such disproportion has ever been found in experiments on the hydrolysis of choline-esters. This phenomenon has always been taken into account in those experiments in which distribution of activity over different parts of the insect body was studied.

\section{DISCUSSION AND CONCLUSIONS}

From the data given in Tables 2 and 4 on distribution in the insect body and on inhibition by eserine it is clear that at least two different enzymes must be concerned in the hydrolytic processes studied.

Four arguments may be adduced in support of the view that all choline-esters are hydrolysed by one and the same enzyme, which in general has the characteristic 
properties of the specific cholinesterase as found in mammalian brain and erythrocytes (Augustinsson, 1950).

(1) The hydrolysis of all choline-esters studied is inhibited by excess substrate. The rather high activity to butyrylcholine as compared to acetylcholine constitutes a clear deviation from the main pattern of true mammalian cholinesterase and suggests the occurrence of a second, non-specific, cholinesterase, such as the pseudo-cholinesterase of mammalian blood plasma. This suggestion is supported by the finding of Metcalf, March, and Maxon (1955), that the pSactivity curve for the hydrolysis of butyrylcholine is S-shaped. The absence of auto-inhibition found by these authors was not confirmed, however, by WoLfe and SMALlMaN (1956) and is in contradiction with our own results.

(2) The distribution of the hydrolysing activities to different choline-esters in the housefly body is strikingly similar (Table 2). It is distinctly different from that found for the other esters mentioned in Table 2, particularly that for methylbutyrate and tributyrin.

(3) The hydrolysis of different choline-esters is equally inhibited by DDVP and eserine (see Table 3, experiments 1 and 3 , and Table 4). A correct interpretation of the results of Experiment 3. (Table 3) should take account of the proportionality of the inhibitor concentrations required and the homogenate concentrations used. The hydrolysis of the choline-esters studied was invariably nearly. 100 per cent inhibited by high concentrations of eserine (Table 4). In contrast with this the inhibition of the hydrolysis of all other substrates was much less. The data reported here irrefutably prove that no eserine-resistant enzymes are concerned with the hydrolysis of any of the choline-esters under investigation.

(4) None of the summation-experiments on pairs of choline-esters showed any summation of hydrolytic activities (see Table 5, experiments 1-5). As pointed out before this is no absolute proof that only one enzyme is involved, but it may be considered as strong evidence in favour of this view.

A serious drawback of the $a$-conditions in preparing the homogenates used in the experiments shown in Table 5 lies in the possible inactivation of esterases, such as those hydrolysing methylbutyrate and tributyrin. If such labile esterases should take part in the hydrolysis of any of the choline-esters, this would not necessarily appear from the results of the summation-experiments. The stability of the acetylchnline hydrolysing capacity of homogenates proves that no labile esterases are concerned with the splitting of this substrate.

The available evidence thus points to one single enzyme being responsible for the hydrolysis of all choline-esters, This enzyme will henceforth be indicated by the name cholinesterase.

Some further conclusions with regard to affinities between the cholinesterase and different choline-esters can be drawn from the data in Table 5 .

(a) The first three experiments clearly show that butyrylcholine is hydrolysed more slowly than acetylcholine at substrate concentrations which are near optimal (see also Table 1). This must be due to a lower turnover number for butyrylcholine- than for acetylcholine-hydrolysis. This lower turnover number, however, is attended by a much higher affinity for the enzyme, as is clearly brought 
out by the results of those experiments in which both substrates are used simultaneously. The hydrolytic rate then found is almost equal to that observed with butyrylcholine alone, indicating a nearly complete displacement of acetylcholine from the active surface of the enzyme by butyrylcholine, acting in this case as an inhibitor. This only occurs when both compounds are used at approximately optimal substrate concentrations. If the concentration of acetylcholine is raised, it is better able to compete with butyrylcholine and the hydrolysis rate is equal to or even lower than that for acetylcholine alone, which, as a consequence of autoinhibition, is then very low. These findings are in full agreement, at least qualitatively, with the findings of BERGMANN and SHIMONI (1953) concerning the electric eel cholinesterase.

(b) Unlike butyrylcholine, benzoylcholine is not hydrolysed at an appreciable rate. However, its affinity to the enzyme, like that of butyrylcholine, is distinctly higher than that of acetylcholine. From the results of Experiment 4 it may be calculated that 50 per cent inhibition of acetylcholine hydrolysis (at an acetylcholine concentration of $1.5 \times 10^{-2} \mathrm{M}$ ) is obtained with approximately $0.5 \times 10^{-2} \mathrm{M}$ benzoylcholine. At equal concentrations of both choline-esters $\left(1.5 \times 10^{-2} \mathrm{M}\right)$ the inhibition amounts to 79 per cent, roughly indicating the ratio of the affinities for benzoylcholine and for acetylcholine to be about 4. A similar inhibition by benzoylcholine, though much weaker, has also been described by LEHMANN and SILK (1955) for human red cell cholinesterase.

(c) The results of Experiment 5 show that the affinity of acetyl- $\beta$-methylcholine to the cholinesterase is somewhat less than that of acetylcholine. The much lower rate of hydrolysis obtained with acetyl- $\beta$-methylcholine as compared to that with acetylcholine (see also Table 1) in our view, cannot be explained, however, by this rather small difference in affinity.

Methylbutyrate and tributyrin are hydrolysed by some ensyme other than the cholinesterase. The arguments in favour of this view may be summarized as follows:

(1) The distribution of the methylbutyrate- and tributyrin-splitting capacity in the body is distinctly different from that of the cholinesterase (see Table 2).

(2) The capacity of homogenates to split methylbutyrate and tributyrin is greatly reduced under conditions (temperature $37^{\circ} \mathrm{C}$, slightly alkaline medium) which do not affect the activity of the cholinesterase.

(3) Eserine concentrations completely inhibiting the cholinesterase activity do not appreciably affect the hydrolytic breakdown of methylbutyrate and tributyrin (see Table 4).

This eserine-resistant and heat-alkali-labile enzyme will be referred to as the ali-esterase (MetCALF, Maxon, FuKuto, and March, 1956).

The Experiments 7-9 of Table 5 give some information on the possibility of cross-inhibition, i.e. inhibition of the cholinesterase and the ali-esterase by each other's substrates. In the Experiments 7 and 8 the ali-esterase activity, most probably as a consequence of heat-alkali-inactivation ( $a$-conditions), is very low, which greatly facilitates the interpretation of the results. These possibly point to a weak inhibition of the cholinesterase-activity by the presence of high 
concentrations of methylbutyrate. In Experiment 9 ( $b$-conditions) an obvious but incomplete summation of hydrolytic activities was observed. This points to a weak inhibition of either enzyme by the substrate of the other.

It may be questioned whether there is only one ali-esterase concerned with the hydrolysis of methylbutyrate and tributyrin. Heat-alkali-inactivation experiments not reported in this paper indicate that possibly two or even more enzymes are present with slightly different properties, for example with respect to substrate preference. In our view, this possibility is of only little importance for the present subject and we feel ourselves justified, therefore, to deal with the hydrolytic activity to methylbutyrate and tributyrin as if brought about by onc ali-csterase.

Now that the occurrence of two esterases with distinctly different substrate specificities has been established, the problem arises as to whether it is possible to explain the hydrolysis of the other substrates studied by the action of these two esterases.

(1) Methylacetate. The hydrolysis-rate, even at very high concentrations, is low (Table 4). Only 8 per cent of the activity of whole fly homogenates is inhibited by $10^{-5} \mathrm{M}$ eserine. This result could most easily be explained by ascribing a small part of the activity to the eserine-sensitive cholinesterase and the remainder to the action of the eserine-resistant ali-esterase. The activity of the cholinesterase to methylacetate must be very low.

(2) Ethylacetate. What has been said with respect to methylacetate also applies to ethylacetate (Table 4). Cholinesterase activity to this substrate is very low and accounts for a small part only of the total hydrolytic activity.

(3) Amylacetate. This is hydrolysed much faster than methyl- and ethylacetate (Table 4). Probabiy most of the activity reported for the heads (Table 1 ) is due to the cholinesterase, especially since we were unable to demonstrate any appreciable ali-esterase activity in the heads under the $a$-conditions used in this experiment. This view is confirmed by the data given in Table 3, Experiment 4 (equal $I_{50}$ values for DDVP-inhibition for acetylcholine and amylacetate) and by those given in Table 5, Experiment 10 (no summation of activities to acetylcholine and amylacetate). The results of an eserine inhibition experiment on whole fly homogenates (Table $4, b$-conditions), however, clearly show that only about one half of the total hydrolytic activity is due to the cholinesterase and the other half to the action of an eserine-resistant esterase, at least if an amylacetate-emulsion (saturated solution contains about $1.4 \times 10^{-2} \mathrm{Mol} / 1$., at $18^{\circ} \mathrm{C}$ ) is used. It is still uncertain whether this latter esterase is identical with the aliesterase mentioned before.

(4) Triacetin. This substrate is very well split by flyhead homogenates, at high concentrations even faster than acetylcholine (Table 1). The data obtained in the DDVP-inhibition experiment (Table 3,2) and the substrate-summation experiment (Table 5,6 ) suggest this activity to be mainly due to the cholinesterase. Calculation of the distribution in the body of the eserine-sensitive part of the hydrolytic activity from the data given in Table 4 shows that 68 per cent is present in the head and 32 per cent in the remainder of the body. This confirms the 
idea that triacetin-hydrolysis is for a major part brought about by the cholinesterase. The data in Table 4 also show that part of the hydrolytic activity to triacetin must be due to some eserine-resistant esterase, for which the distribution between the heads and the remainder of the body can be calculated to be in the proportion of fifteen to eighty-five, which is reasonably similar to that found for the ali-esterase.

Summarizing, it can be concluded that, if triacetin is used in $5 \times 10^{-2} \mathrm{M}$ concentration, the hydrolysis is performed by $a$, the cholinesterase in the head, $b$, the cholinesterase in thorax and abdomen, $c$, the ali-esterase in the head, and $d$, the ali-esterase in thorax and abdomen, to the extent of $46,22,5$ and 27 per cent respectively.

(5) Phenylacetate. This substrate has been intensively studied by LORD and POTTER (1954), who concluded that its hydrolysis in a number of insect species is brought about by an esterase which is distinctly different from the cholinesterase. Our experiments show that the hydrolysis of phenylacetate by housefly homogenates, even at rather low substrate concentrations, proceeds rapidly (Table 1) and that part of it is inhibited by $10^{-5} \mathrm{M}$ eserine (Table 4). Calculation of the distribution of the eserine-susceptible activity gives values of 67 per cent for the heads and 33 per cent for thorax and abdomen. Apparently this activity is due to the cholinesterase. The major part of the hydrolysis by whole fly homogenates, however, has to be ascribed to an eserine-resistant enzyme, of which, according to calculation from the data in Table 4, 18 per cent is present in the head and 82 per cent in the remainder of the body. This suggests this cnzyme to be identical with the ali-esterase mentioned before. Most probably, therefore, phenylacetate is split both by the cholinesterase and by the ali-esterase, the latter enzyme being, at least quantitatively, the most important.

(6) $o$-Nitrophenylacetate. HopF (1954) studied the hydrolysis of this ester by homogenates of the thoracic nervous system of Locusta migratoria. He concluded that possibly one 'acetylesterase' is responsible for the breakdown of $o$-nitrophenylacetate and acetylcholine and found no evidence for the existence of a specific acetylcholinesterase.

The present investigations permit the following conclusions.

(a) The hydrolytic activity of flyhead homogenates to $o$-nitrophenylacetate is high (Table 1). Results of experiments with flyhead homogenates, not reported in this paper, point to a marked independence of the activity of the substrate concentration, e.g. lowering the concentration from $2 \times 10^{-3} \mathrm{M}$ to $2.5 \times 10^{-4} \mathrm{M}$ caused a decrease of only some 20 per cent or less of the hydrolytic rate. This shows that even at very low concentrations the hydrolytic enzyme is nearly saturated with the substrate. This is confirmed by the data given in Table 6 for the hydrolysis of $o$-nitrophenylacetate at $10^{-3}$ and $2 \times 10^{-3} \mathrm{M}$ concentrations.

(b) According to the data of Table 4 a part of the hydrolysis is performed by some eserine-sensitive enzyme. Calculation shows that 70 per cent of this enzyme is present in the head and 30 per cent in thorax and abdomen, which points to its identity with the cholinesterase. Further evidence for this view can be got 
from Experiment 5 of Table 3 with flyheads, which shows about equal inhibition of acetylcholine- and $o$-nitrophenylacetate-hydrolysis by DDVP.

(c) There can be no doubt as to the occurrence of an eserine-resistant esterase splitting o-nitrophenylacetate, which according to the data in Table 4 (c-conditions) is mainly present in thorax and abdomen (calculation in one experiment gives a value of 83 per cent, in another 94 per cent). The hydrolysis in thorax and abdomen may thus be due to the ali-esterase mentioned before, but the evidence is not conclusive.

According to the data given in the previous section there also exists an organophosphate-resistant enzyme splitting o-nitrophenylacetate.

$(d)$ The results of two summation experiments with head homogenates are shown in Table 6. The colorimetric techniques used there made it possible to determine the two substrates separately, since the sum of acetylcholine and $o$ nitrophenylacetate can be estimated by the Hestrin-method (equimolecular solutions of these two compounds give equal colour intensities in this method), whereas the amount of $o$-nitrophenylacetate can be obtained by a colorimetric determination of $o$-nitrophenol:

The competition of acetylcholine and o-nitrophenylacetate for the cholinesterase is clearly demonstrated by the distinctly lower acetylcholine-hydrolysis in the presence of $o$-nitrophenylacetate. According to the inhibition of the hydrolysis of $o$-nitrophenylacetate by acetylcholine the same applies to the enzyme splitting $o$-nitrophenylacetate. It is probable, therefore, that both substrates are hydrolysed by the same enzyme-cholinesterase.

Adding up all the evidence on $o$-nitrophenylacetate, the most plausible conclusion seems to be that the hydrolysis of $o$-nitrophenylacetate in flyhead homogenates is largely performed by the cholinesterase and that in homogenates of thoraces and abdomens mainly by some other enzyme which possibly is identical with the ali-esterase.

(7) Ethylbutyrate. 'The rate of hydrolysis by whole fly homogenates proved to be about similar to that of methylbutyrate at equimolecular concentrations (see Table 1). It is believed that ethylbutyrate splitting is accomplished by the aliesterase, but experimental proof for this view is lacking.

Surveying the results obtained with the seven substrates, the following statement can be made. All acetic acid esters studied are hydrolysed by the cholinesterase. The hydrolytic rate is low for the short chain acetates, such as methyland ethylacetate, but increases with increasing size of the alcoholic (or phenolic) portion of the substrate molecule. This may possibly be explained by assuming that the cholinesterase prefers those substrates, of which the dimensions are approximately equal to those of acetylcholine. The affinity of the cholinesterase for $o$-nitrophenylacetate is remarkably high and may be about equal to that for acetylcholine. Though arguments may be adduced for using the term 'acetylesterase' (Hopf, 1954) rather than cholinesterase, we believe that the latter is preferable on historical grounds as well as for the reason that choline-esters, including butyrylcholine, are exclusive substrates with very high affinities to this enzyme. 
Although the ali-esterase found in houseflies may provisionally be defined as the enzyme capable of splitting methylbutyrate, it must be stressed that much higher rates of hydrolysis are obtained with phenylacetate, at least if comparison is made at the same molar substrate concentrations. As outlined above, several other acetates are also appropriately split by the ali-esterase.

Summing up once more it seems justifiable to ascribe most of the hydrolysis of all substrates studied to the action of two enzymes, which may be indicated by the names cholinesterase and ali-esterase.

\section{SUMMARY}

The hydrolytic activity of homogenates of whole houseflies or parts of houseflies has been investigated. The substrates used were: acetylcholine, acetyl- $\beta$ methylcholine, butyrylcholine, benzoylcholine, methylacetate, ethylacetate, amylacetate, triacetin, phenylacetate, o-nitrophenylacetate, methylbutyrate, ethylbutyrate, and tributyrin.

Most probably the hydrolytic activities towards the different substrates studied can be explained by the action of two main enzymes, a cholinesterase and an aliesterase. The properties of the cholinesterase are more or less comparable to those of the so-called true cholinesterase as found in the nervous system and red blood cells of vertebrates. It is completely inhibited by $10^{-6} \mathrm{M}$ concentrations of eserine, whereas the ali-esterase is eserine-resistant. The inhibition by eserine thus constitutes a reliable means for distinguishing the two enzymes. It was further shown that the ali-esterase is rapidly inactivated at $37^{\circ} \mathrm{C}$ in slightly alkaline media, e.g. $0.025 \mathrm{M}$ bicarbonate-solution in air, whereas the cholinesterase is not affected by these conditions.

The following conclusions can be drawn :

(1) The distribution in the housefly of the cholinesterase and the ali-esterase is distinctly different. The cholinesterase is mainly found in the head (70 per cent) and much less in thorax ( 25 per cent) and abdomen ( 5 per cent). The aliesterase is mainly found in thorax (ca. 40 per cent) and abdomen ( $c a .40$ per cent), and for a minor part only in the head (ca. 20 per cent).

(2) All choline-esters studied are hydrolysed by the cholinesterase only. Hydrolytic rates decrease in the order acetylcholine, butyrylcholine, acetyl- $\beta$ methylcholine, and benzoylcholine. Butyrylcholine and benzoylcholine show greater affinity to the enzyme than acetylcholine, whereas the affinity of acetyl- $\beta$ methylcholine proved to be somewhat lower than that of acetylcholine. Inhibition by excess substrate was shown to occur for the hydrolysis of acetylcholine, butyrylcholine and acetyl- $\beta$-methylcholine. The rate of hydrolysis of benzoylcholine was so small that no reliable results as to the occurrence of auto-inhibition could. be obtained.

(3) Methylbutyrate and tributyrin are hydrolysed by the ali-esterase only. There may possibly be two or even more ali-esterases with slightly different properties involved in their hydrolysis. The evidence for this, however, is still rather weak and no detailed study of this problem was made. 
(4) All other substrates, ethylbutyrate most probably excepted, were hydrolysed partly by the cholinesterase and partly by the ali-esterase. There is some evidence that $o$-nitrophenylacetate-hydrolysis is partly due to an organo-phosphateresistant enzyme distinct from the two esterases mentioned above, which are both inhibited by low concentrations of DDVP and paraoxon.

Acknowledgements-The author wishes to thank Mr. C. H. JANSSEN who did some of the experiments dealt with in this paper, and Mrs. I. VAN DER LINDEN-vaN Esch for her excellent technical assistance. He is especially indebted to Dr. K. A. Lord (Harpenden, G.B.) for much valuable discussion and his willingness to correct the English. Thanks are further due to Prof. Dr. B. Mendel (Amsterdam) for a gift of butyrylcholine perchlorate, to the Montrose Chemical Company (U.S.A.) for a gift of DDVP and to Prof. J. A. A. KetelaAr (Amsterdam) and to Philips-Roxane Ltd. (Weesp-Holland) for supplying paraoxon.

\section{REFERENCES}

ASPEREN K. VAN (1957) Mode of action and metabolism of some organic phosphorus insecticides in houseflies. Proc. 4th int. Congr. Crop Protection, Hamburg 1957. In press.

ASPEREN K. vaN (1958) Mode of action of organophosphorus insecticides. Nature, Lond. 181, 355-356.

ASPEREN K. VAN (1958a) The mode of action of an organophosphorus insecticide (DDVP). Ent. exp. appl. 1, 130-137.

ASPEREN K VAN and DeKHUIJZEN H. M. (1958) A quantitative analysis of the kinetics of cholinesterase inhibition in tissue homogenates of mice and houseflies. Biochim. biophys. Acta 28, 603-613.

Augustinsson K. B. (1950) Acetylcholine esterase and cholinesterase, in The Enzymes 1 (1), 443-472. Academic Press Inc. New York.

Bergmann F. and Shimoni A. (1953) 'The enzymic hydrolysis of alkyl fluoroacetates and related compounds. Biochem. $\mathcal{~ . ~ 5 5 , ~ 5 0 - 5 7 . ~}$

Chadwick L. and Hill D. (1947) Inhibition of cholinesterase by diisopropyl fluorophosphate, physostigmine and hexaethyl tetraphosphate in the roach. $\mathscr{Y}$. Neurophysiol. 10, $235-246$.

Chadwick L. E., Lovell J. B., and EGNer V. E. (1953) The effect of various suspension media on the activity of cholinesterase from flies. Biol. Bull., Woods Hole 104, 323-333.

Chefurka W. and Smallman B. N. (1956) The occurrence of acetylcholine in the housefly, Musca domestica L. Canad. F. Bioch. Physiol. 34, 731-742.

ColHoun E. H. (1958) Tetraethyl pyrophosphate and acetylcholine in Periplaneta americana. Science 127, 25.

Goldstein A. (1954) Substrate summation experiments with cholinesterases. Fed. Proc. $13,358-359$.

Hestrin S. (1949) The reaction of acetylcholine and other carboxylic acid derivatives with hydroxylamine, and its analytical application. F. biol. Chem. 180, 249-261.

HopF H. S. (1952) Injection experiments on the role of cholinesterase inhibition. Ann. appl. Biol. 39, 193-202.

HoPF H. S. (1954) Inhibition of the acetylesterases of the locust nerve cord by some organic phosphoric esters. Ann. appl. Biol. 41, 248-260.

LEHMANN H. and SilK E. (1955) Protection of rabbits against benzoylcholine by injection of pseudocholinesterase. Bioch. $\mathcal{7}$. 59, vii.

LEwIS S. E. (1953) Acetylcholine in blowflies. Nature, Lond. 172, 1004.

LwwIS S. E. and Fowler K. S. (1956) Effect of diisopropyl phosphorofluoridate on the acetylcholine content of flies. Nature, Lond. 178, 919-920. 
Lewis S. E. and Smallman B. N. (1956) 'The estimation of acetylcholine in insects. $\mathcal{F}$. Physiol. 134, 241-256.

LORD K. A. and PUTTER C (1950) Mechanism of action of organophosphorus compounds as insecticides. Nature, Lond. 166, 893.

LORD K. A. and PotTer C. (1951) Studies on the mechanism of insecticidal action of organophosphorus compounds with particular reference to their anti-esterase activity. Ann. appl. Biol. 38, 495-507.

LoRd K. A. and PotTER C. (1954) Differences in esterases from insect species: toxicity of organophosphorus compounds and in vitro anti-esterase activity. $\mathcal{F}$. Sci. Fd. Agric. 5, $490-498$.

Metcalf R. L. (1955) Organic insecticides. Interscience Inc. New York, London. Metcalf R. L., Fukuto T. R., and March R. B. (1958) Mechanisms of action of anticholinesterase insecticides. Proc. 10th int. Congr. Ent. 2, 13-18.

Metcalf R. L., March R. B., and Maxon M. G. (1955) Substrate preferences of insect cholinesterases. Ann. ent. Soc. Amer. 48, 222-228.

Metcalf R. L., Maxon M., Fukuto T. R., and March R. B. (1956) Aromatic esterase in insects. Ann. ent. Soc. Amer. 49, 274-279.

Potter C., Lord K. A., Kenten J., Salkeld E. II., and Ilolbrook D. V. (1957) Embryonic development and esterase activity of eggs of Pieris brassicae in relation to TEPPpoisoning. Ann. appl. Biol. 45, 361-375.

Smallman B. N. (1956) Mechanisms of acctylcholine synthesis in the blowfly. \%. Physiol. 132, 343-357.

Smallman B. N. (1958) The physiological basis for the mode of action of organophosphorus insecticides. Proc. 10th int. Congr. Ent. $2,512$.

Smaldman B. N. and Fischer R. W. (1958) The effect of anticholinesterases on acetylcholine levels in insects. Proc. 10th int. Congr. Ent. 2, 225-226.

Wolfe L. S. and Smallman B. N. (1956) The properties of cholinesterase from insects. F. cell. comp. Physiol. 48, 215-235. 